\title{
The Paradigm of Critical Realism and Involving Educators in Policy Debates'
}

\section{El Paradigma del Realismo Crítico y la Inclusión de los Educadores en los Debates de Política Educativa}

\author{
Juan David Parra ${ }^{2 *}$ \\ Erasmus University Rotterdam, The Netherlands
}

\begin{abstract}
Education policy debates in Colombia often exclude the voice of professional educators. The aim of this paper is to introduce Critical Realism as an alternative to dominant social research paradigms that enables the possibility of more inclusive education policies. The ontic and epistemic elements of CR make a call for an inter-paradigmatic dialogue to retrieve causal explanations by providing scientific value to first-hand living experiences of social actors. In the end, different researchers (i.e. statisticians and school teachers) have a crucial, but differentiated, role, in the quest for scientific discovery.
\end{abstract}

Key words: Education policy, Critical Realism, professional educators, causal knowledge

\section{Resumen}

Los debates sobre política educativa en Colombia tienden a excluir la voz de educadores. El objetivo de este artículo es presentar el Realismo Crítico como una alternativa a paradigmas dominantes en las ciencias sociales y que abre la posibilidad a una política educativa más inclusiva. Los elementos ontológicos y epistemológicos del RC hacen un llamado al diálogo interdisciplinario en la producción de explicaciones causales, por medio de la atribución de valor científico a las experiencias directas de diferentes actores sociales. Al final,

Received: Dec. 15, 2014 / Accepted: April 16, 2015

jparrah@gmail.com 
diferentes investigadores (ej. estadísticos, docentes) tienen un papel crucial, pero diferente, en la búsqueda de conocimiento científico.

Palabras clave: Política educativa, realismo crítico, educadores profesionales, conocimiento causal

\section{Resumo}

Os debates sobre política educativa na Colômbia tendem a excluir a voz de educadores. O objetivo deste artigo é apresentar o Realismo Crítico como uma alternativa a paradigmas dominantes nas ciências sociais e que abre a possibilidade a uma política educativa mais inclusiva. Os elementos ontológicos e epistemológicos do RC fazem uma chamada ao diálogo interdisciplinar na produção de explicações causais, por meio da atribuição de valor científico às experiências diretas de diferentes atores sociais. No final, diferentes pesquisadores (ex. estatísticos, docentes) têm um papel crucial, mas diferente, na procura de conhecimento científico.

Palavras chave: Política educativa, realismo crítico, educadores profissionais, conhecimento causal

“... as reform after reform is proposed, nobody ever seems to turn to actual teachers and ask, 'So, what do you think?' Yes, we occasionally hear from Teachers of the Year and other carefully selected and screened teachers. But by and large, leaders have been trying to remake the entire education world without involving the people who have devoted their lives to working in it (...) I am far from the halls of power (...) As the great opera about American public education plays out, I am, like most classroom teachers, watching from the back rows of the balcony"

Greene (2014) 


\section{Introduction}

$\mathrm{E}$ ducation public policy debates in Colombia often exclude the voice of professional educators. This statement finds support not only in a general revision of research projects sponsored by school performance education authorities (see Appendix), but, particularly in the critical reading of mainstream policy-prescriptions. Such is the case of the Compartir Report (Jaramillo et al., 2014), which has become an institutional guideline to backup educational reforms, and the way it contributes to impoverish the general view of teaching and learning. The authors of this document follow a similar tradition of worldwide managerial educational trends shaped by the popular McKinsey reports, where it is possible to identify a technocratic tendency to regard the mind of learners "as containers to be filled with knowledge" (Coffield, 2012, p. 140), and hence, the role of teachers as passive learning tools who need to be selected, trained, incentivized and evaluated.

With the latter we are not seeking, however, to undermine the importance of good managerial decisions as a requirement to improve learning processes in schools. We even subscribe to the argument of the need of seeking higher standards in the professional qualities of teaching bodies. However, we find problematic the way in which mainstream policies systematically rule out the agency of teachers by implicitly neglecting their role in the building of useful knowledge to backup different policy initiatives. The issue is that this technocratic practice -as it will be argued through out the document- is backed up by a flawed foundation of what is causal knowledge (i.e. the identification of statistical correlations between atomized variables) that reproduces structural barriers to the transformation of schools. Hence, we declare our rather pessimistic outlook about the expected results of ongoing national educational projects [for similar visions see Coffield (2012), Álvarez (2014) and Montoya-Vargas (2014)].

The scope of this article is situated within this methodological discussion. As the task of deconstructing the McKinsey reports - also enthusiastically quoted in the context Colombia's Decennial Education $P{ }^{3}{ }^{3}$ - has been fairly covered in Braun (2008) and Coffield (2012), we will take the Compartir Report as a case study to discuss the scientific short-comings behind mainstream policy planning in the country. Our

3 See http://www.mineducacion.gov.co/1621/article-195576.html 
criticism will be framed within the paradigm Critical Realism (CR $)^{4}$, an epistemic stand whose contributions in the elucidation of notions of scientific rigor in social research has fostered its potential in shaping contemporary education theory. For our particular case, critical realist commentators would argue that any process of scientific discovery implies delving into the unknown, a task that can benefit from the vast experience of those who embody, for instance, the day-to-day execution of education policies.

In the first part of the article we will explore the assumptions behind the paradigm that informs mainstream educational policy in order to understand the methodological foundations behind the policy prescriptions of the Compartir Report. Here we will also dedicate some lines to discuss why alternative agendas undertaken by other researchers (i.e. more postmodern oriented scholars) have also failed in the task of integrating the voice of teachers into education policy debates. Then, the main tenets of $\mathrm{CR}$ will be introduced as a means to further understand the pitfalls and shortcomings of dominant research paradigms when informing education policy, and finally, CR applied literature will be used to seal the argument of the epistemic and scientific status of teachers' agency in processes of education planning and assessment.

\section{Dominant Research Paradigms and the Exclusion of Teachers from the Debate}

From an epistemological perspective, education policy is dominated by positivism (Scott 2010; Willmott 2002), a paradigm "predicated on an observation-based model for determining the truth or validity of knowledge" (Kanbur \& Shaffer, 2007, p. 185). Following Summer \& Tribe (2008), positivist thinkers - most of which are historically influenced by the ideas of XXth century philosophers of the Vienna Circle and, more recently, by Popper's falsification principle- praise principles of commensurability and experience as epistemic paths to access objective and uncontested knowledge. This helps us to understand why, and in spite of the relative success of

4 The Paradigm of Critical Realism has grown in popularity in the recent decades and especially in Northern Europe. It is important to note its relative absence in the North American academy, and therefore, in Latin-American universities, most of which have been importantly permeated by positivist research traditions from the United States [see Porpora (2001) and Parada (2004)]. Hence, one of the innovations of this article is that it becomes the first effort to use CR as an analytical device to face a public policy debate in Colombia (and one of the very few in the Latin American context). 
ongoing education policies (Barrera et al. 2012; García-Villegas et al. 2013; Montoya-Vargas, 2014), experts in statistical analysis keep monopolizing educational research.

The Compartir Report (Jaramillo, et al., 2014) ${ }^{5}$, whose influence on current education planning serves to equate it as a contemporary hallmark of mainstream education policy research ${ }^{6}$, is a good example of this last situation. The main finding of the document, coauthored by five highly qualified scholars in the arena of economics and quantitative social policy research, states that "teaching quality contributes more than any other school input in explaining differences in students' performance" (Jaramillo, et al., 2014, p. 13). Such a conclusion follows from the results of an original empirical (econometric) exercise and a systematic analysis of international experiences of school success. As it is explicitly argued, despite other relevant factors affecting school performance -such as socio-economic contexts or the investment in technology and infrastructure- teaching quality is identified as the single most important determinant of children's learning.

We argue that the epistemic stands behind the Compartir Report bare particular implications. One of them is the resulting topdown approach to answer the public policy conundrum: to provide better training, better selection mechanisms (including post-selection evaluations) and higher wages for teachers (see Jaramillo, et al., 2014, pp. 268-322). At the same time, the arrival to such strategies demands not only the possession of particular researching skills - i.e. computational proficiency to handle big data sets and training in applied econometrics- but an adherence to assumptions that praise certain logics of simplification; for example, the possibility of discerning between levels of impact (at least in such a precise way) suggests that some complex concepts, as for instance the interaction of teachers and students in the classroom (i.e. didactics and pedagogics), the managerial relation between teachers and administrative staffs in schools and the appropriation of institutional projects among members of a community, have to be captured in (as simple as possible) indicators.

Epistemologically speaking, it is worth pointing out that this line of thought praises the use of representative statistics as a shield against ideological biases in policy assessments (or, following the introductory

This study was funded by Fundación Compartir, a private firm dedicated to the promotion of high-impact social programs in education.

6 See, for example, the article "Hicimos de los docentes el eje de la transformación educativa" published in the web site of the National Ministry of Education at http:// www.mineducacion.gov.co/cvn/1665/w3-article-337974.html 
remarks of the report, "to leave intuition aside (...) [as well as] the interests of determined groups" (Jaramillo et al., 2014, p. 2)). These kinds of arguments are founded in notions of empiricist objectivity and the way it implicitly validates the possibility of accessing causal knowledge through means of perception. Hence, good policy assessments are those "conducted by an external group to maintain objectivity and credibility" (Gertler, et al., 2011, p. 155) and whose "scientific and normative standards are driven by empirical [and] objective data" (Judd, et al., 2001, p. 367).

At this point, it becomes clear why policy prescriptions that emerge from epistemic frameworks such as the one backing up the Compartir Report tend to leave aside teachers' agency (i.e. their active participation) from policy making processes. On one hand, and given its implicit concept of scientific rigor, much more attention is placed on "methodological questions relating to data collection, software design [and] data analysis" (Milani, 2009, p. 29), than for instance, in debating underlying assumptions regarding causation or human behavior (i.e. social relations and interactions). We argue that this tendency to hierarchize technique over the problem at stake results in a paradox in which the expertise of professional educators-i.e. in curriculum building, in pedagogics- is given (at best) a secondary role in the generation of policy inputs.

Furthermore, such pursuit of neutrality and credibility, which is (importantly) defined in terms of statistical representativeness, also shapes the actual role given to teachers' knowledge as key informants about what happens in schools. In such sense, as teachers' perceptions are molded from their experience in only a few classrooms, their personal views are given only anecdotal status (one reason why it is better to survey them in a big scale and with pre-structured questions) ${ }^{7}$. In the end, as it has been pointed out in Milani's (2009) critical reading of policy documents from several international agencies (i.e The World Bank, United Nations, The European Union), "researchers and practitioners do not speak the same language (...) [and basically] operate in isolation from each other" (p. 36).

Now, we find it convenient to close this section by referring to some non-mainstream perspectives seeking to inform policy debates.

7 Is worth pointing out that the Compartir Report does include a qualitative chapter in which the consultancy team retrieves information from some schools. This, however, and as will be discussed later on, is also done under the scope of a positivist tradition in which structured interviews are used only as a mean to validate quantitative findings. In such sense, teachers continue to play a passive role in the whole policy discussion. 
We can classify these as more postmodern-oriented research traditions which, in spite of their explicit recognition of the transformative role of educators (Herrera \& Acevedo, 2004), have also failed in raising the voice of professional educators. Here we summon MontoyaVargas's (2014) extensive literature review on the topic to argue the way in which an important portion of educators' research agendas has been overshadowed by its emphasis on pedagogics and didactics, leaving aside deeper immersions into curriculum analysis ${ }^{8}$. Conversely, those who do delve into education politics show more interest in deconstructing mainstream policy discourses (as we have partially done so far) than in giving a step forward into generating policy alternatives.

As in the case of positivist-oriented positions (i.e. The Comparir Report), we can also refer to epistemic foundations to elucidate some nuances of postmodern research traditions. An important one is their particular stance in regard to notions of objectivity and truth and, in that sense, their adherence to the premise that "reality does not exist independently from our experiences" (Summer \& Tribe, 2008, p. 61). Hence, postmodern-oriented scholars would argue, and in complete opposition with positivism, "that truth and objectivity themselves must be abandoned" (Porpora D. , 2001, p. 263), precisely because any notion of reality depends on a subjective interpretation. Methodologically speaking we are not just referring, therefore, to an explicit preference for qualitative research, but to particular methods to identify "how understanding and experiences are derived from lager discourses" (Zeeman, et al., 2002, p. 98) ${ }^{9}$.

Why are we saying that postmodernism also fails to boost teachers' agency into the education policy debate? Porpora's (2001) statement illustrates quite well the argument we want to defend here; "[i]f there is no [concept of] truth or objectivity, if judgmental rationality is rejected, then there is no point in carrying on inter-paradigmatic dialogue" ( $p$. 263). Said differently, in a world where public policy is only part of a

8 If we understand curriculum studies as a constant dialogue about the kind of education that seeks a society (Johansson, 2003), we must conclude that, according to MontoyaVarga's (2014) outlook, professional educators are not actively talking about education politics.

9 Montoya-Vargas (2014) discusses, for instance, the case of the research agenda of the Pedagogy and Curriculum group from Cauca University, a leading collective of academic educators: "These authors apply a historic and hermeneutic approach to the study of 150 documents about the curriculum produced between 1960 and 1975 (...) The group restates the origins of the curriculum as an utilitarian, market oriented control and power device imposed by international agencies, dominated by the USA through the [Ministry of Education] to control education ideologically (...) and to disempower teachers" (p. 139). 
hegemonic discourse it makes little sense to reflect on how to improve the impact of social programs (for instance, through an open dialogue between economists and scholars from education faculties). Hence, we talk about a possible self-exclusion sustained by an implicit refusal (legitimate or not) to talk about education policy. At the same time, such a stand also enforces the exclusion of professional scholars from mainstream policy circles, which -in their own understanding of scientific rigor- are tempted to reject any kind of ideological argument that defaults their sense of objective research ${ }^{10}$.

\section{Critical Realism and the Meaning of "Good" Science}

Critical Realism has grown in popularity in the last two decades -especially in the United Kingdom and in northern European countriesand particularly in the field of educational research (Archer, 2013; Priestley \& Miller, 2012; Scott, 2010; Willmott, 2002;). However, our argument to defend its pertinence transcends simple recognition. To further sustain its adequacy we adhere to Sayer's (2000) presentation of $\mathrm{CR}$ as "conceptually cautious and more reflexive about both its implicit philosophy and methodology and its social and political coordinates" (p. 9) than (most) current dominant research paradigms.

Here we are far from interested in doing an exhaustive presentation of CR, but one that is sufficiently illustrative to help us argue its scientific rigor and its openness towards inter-paradigmatic dialogue. In this regard, we want to be clear about the fact that we are talking about a research paradigm, and not a social theory, a specific methodology or a method. Further on we will see the importance of this last precision vis-à-vis the idea of interdisciplinarity and the possibility of involving different methods and voices into policy debates. For the sake of clarity, our presentation will be further illustrated by briefly discussing elements from relevant empirical research.

\section{Introducing Critical Realism}

What is social science? What is the purpose of social science? What do social scientists do? CR scholars give a great deal of importance to these kinds of reflections. The question about what is out there in the (social) world to be discovered, they would argue, necessarily precedes matters on how to discover or create knowledge about such

${ }^{10}$ See, for example, Pisados por Fecode published in http://www.eltiempo.com/archivo/ documento/CMS-13791659 
(social) world (Bhaskar, 1998). And while the former claim can lead to the obvious- how can we think about the way we are going look for something if we have not tried to imagine what that something looks like - Critical realists highlight the way in which dominant research paradigms tend to obviate the importance of both conceptualizing and distinguishing between ontology (the what question) and epistemology (the how question).

The CR approach to social research stems from a critical reading of the process of scientific discovery in natural sciences and its quest for knowledge (Bhaskar \& Hartwig, 2010). Natural scientists use experiments to "discover, detect, reveal, search out, etc., something about reality that [is] not yet known, something that could not be observed without great effort" (Danermark, et al., 2002, p.20). In Collier's (1994) terms, "we use experiments in order to find what goes on when we are not making experiments, and we do not find it out" (p. 35). One classic example is the case of water (H2O), whose unveiling of its constitutive elements - Hydrogen and Oxygen - and their relational process - i.e. two hydrogen atoms covalently bounded with one of oxygen- requires and experimental procedure (i.e. electrolysis) that goes beyond simple tasting (or drinking).

This reading of experiments bares particular implications ${ }^{11}$. Regarding the ontic question (what exists?), there are things that exist despite our perception (or ignorance) of them and that have causal effects on those things that we actually perceive. It is to say, it is possible to conceive the world as a layered structure in which it is important to differentiate between things that we can perceive (the empirical world) and those things making them possible (their real causes). The case of water - as compounded by elements operating in different layers-

${ }^{11}$ This reading differs from the most classical hypothesis-testing vision of scientific research, described by Bunge (2011) as an arbitrary research project: "Choice of background knowledge-statement of problem(s) - tentative solution (e.g., hypothesis or experimental technique)-run of empirical tests (observations, measurements, or experiments) - evaluation of test results - eventual correction of any of the preceding steps, and new problems posed by the finding" (p. 413). In this case, experimental procedures (which in social sciences are usually confronted through the use of statistics) are used as a device to test pre-given hypotheses, rather than to explain observed facts (i.e. the properties of water). In this regard, Bunge (2011) adds that "[c]ontrary to widespread belief, the scientific method does not exclude speculation: it only disciplines imagination. For example, it is not enough to produce an ingenious mathematical model of some domain of facts, the way mathematical economists do. Consistency, sophistication and formal beauty are never enough in scientific research, the end product of which is expected to match reality-i.e., to be true to some degree" (p. 413). 
perfectly illustrates it in natural sciences. Similar logic applies to the social world; for instance, and in the specific case of education, a school should be seen as a stratified entity "comprising individuals [and] social groupings (such as departments)" (Priestley \& Miller, 2012, p. 102)

Stratification, however, should not be mistakenly read as a linear relation (or simple adding up) between things (or entities) that belong to different strata. In our last examples, despite the flammability of hydrogen, water does not bare this property (Willmott, 1999). Conversely, a school is not a simple amalgam of individuals and departments, but can only exist if certain conditions - or certain internal relations between those entities (Archer, 1995) - meet (i.e. a cultural concept of education, a functioning permit issued by a local or national authority). This notion of relational emergence - which "describes a particular sort of relation between a whole and its parts at a given moment in time" (Elder-Vass, 2010, p. 67) - bares methodological implications that we will discuss later on. With such concepts at hand, we are also entitled to talk about mechanisms to refer to those relational processes that occur between levels of the world.

Now, going to epistemology, the answer to the how to discover question in natural sciences is experimentation, where it is possible to work under controlled situations. It is to say, natural scientists work with closed-systems where they can sustain that "every time A occurs, B, follows" (Collier, 1994, p. 34). The notion of closure allows them to uncover mechanisms and identify entities operating in different layers of the world, particularity that can hardly (if not impossibly) be resembled in social research. As social scientists work in open systems, "[t]he events that [they] can ordinarily observe are not invariable preceded or followed by any other constantly conjoined event" (Collier, 1994, p. 34) ${ }^{12}$. The implication here is that scholars in humanities have to pursue the challenge of uncovering mechanisms through different paths as from the ones of laboratory experiments, but without disregarding the layered condition of the world. Logics of abstraction, guided by, for instance, counterfactual questions - What does the existence of this object/practice presuppose? (Sayer, 2000, p. 16) - can serve to this epistemic purpose.

12 As Collier (1994) further argues, “...[r]ed sky at night is not always followed by a fine day, or deflationary budgets by reductions of inflation, or buglers entering by dogs barking, or spots on the sun by war, or sexual intercourse by conception" (p. 34). 


\section{Flaws and Misconceptions in Mainstream Research}

We insist on the importance of highlighting the status of CR as a research paradigm, rather than an actual social theory. In such sense, "CR acts as a general orientation to research practice (...) [and] does not provide the concepts (or prescribe the methods) that are necessary for successful empirical research" (Mahoney \& Vincent, 2014, p. $13)^{13}$. This precision is very important, as it reinforces one of the most important claims that we have sustained so far; arguments of being are different from arguments of knowing. In other words, as epistemology cannot be reduced to ontology, the existence of specific objects cannot be conditioned to particular paths of enquiry (i.e. observation, quantification, deliberation). Furthermore, to sustain that there are real objects (i.e. real causes) does not entail that we are always successful in identifying them.

The latter is not trivial. As a matter of fact, dominant research paradigms do conflate these matters (Bhaskar, 1998; Collier, 1994; Sayer, 2000). On one hand, positivist researchers tend to equate reality to measurable facts and, hence, to theorize about causality only through the means of what is observed -which is another way of saying that their ontic notion of reality is reduced to their epistemic conception on how to unveil it-. This also drives them, for example, to disregard notions of relational emergence, as they praise an implicit notion of linear-causality. For instance, large-scale multivariate analyses press on towards some predictive goal "without reference to the interactional processes generating their variables" (Archer, 1995, p. 58). More postmodern oriented researchers, on the other hand, are also prey to empiricism, as they tend to only work with observable discourses (Wuisman, 2005).

It is now time to go back to the examples we discussed previously, and the ontic and epistemic elements that were introduced to situate our critique of the methodological flaws of dominant education research informing education policy in Colombia. We have decided

${ }^{13}$ Bunge's (2011) reflections on the theory of knowledge are, once again, elucidating. For instance "[s]cientific research has philosophical underpinnings because it is, in a nutshell, the honest search for true knowledge about the real world (...) Indeed, philosophy is the study of the most fundamental and cross- disciplinary concepts and principles. Hence, philosophers are expected to be generalists rather than specialists" (p. 431). All these clarifications are important to answer some critiques of the critical realist paradigm, most of which address is lack of practical methodological claims. The latter no to justify the neediness for actual social theory, which CR does offer, but to clarify that the discussion on methods cannot be equated to levels of ontology and epistemology. 
to focus on the Compartir Report, whose main analytical tool is the use of econometric models to identify characteristics of high and low performing schools in the country (according to both PISA results and Saber 5 and 9 test scores from the year $2009^{14}$ ). Here it is important to recognize two particular aspects that have been raised by the authors in order to have a proper reading of their results. The first one states that:

[Our] evidence is not causal, in the way that it is based in statistical associations that have not been manipulated in an exogenous way, as it could happen in an experiment [a fact that, however, does not seem to enable them to conclude that]: [T] he accumulated body of empirical evidence coincides in that is justifiable to prioritize the quality of teachers within any policy that seeks to improve the quality of education. (Jaramillo, et al., 2014, p. 66)

On the other hand, the authors briefly describe a qualitative exercise that consisted in visiting four schools (that represent extreme cases of high and low performance) and the application of semistructured interviews (with school deans) and focus group (with teachers) to deepen aspects of interest for the research. In their own words, this last set of tools allowed them "to validate the results from the quantitative component, as the educational level of teachers in schools of high performance is higher than the one from the participants in the schools of low performance" (Jaramillo, et al., 2014, p. 193).

We can now consider how these research elements fail to comply with the principles of CR. On one hand, we can identify an excessive reliance on the use of inductive logics, or the practice of "inferring propositions about general regularities (...) from a limited set of sensory observations" (Wuisman, 2005, p. 367). It is to say, the authors of the Compartir Report present econometric exercises with samples of students to conclude about the quality of education in Colombia, and whose findings are presented in linear terms: every time A occurs (i.e. highly qualified teachers), B (high school performance), follows. Clearly, following earlier discussions, this kind of induction is problematic as it implies making assertions that are only possible in closed systems (Lawson, 1997), and that, hence, disregard notions of stratification and relational emergence.

${ }^{14}$ Saber exams are Colombia's equivalent for SATS or standardized exams to monitor education performance in different moments of child's learning and are administrated by the Colombian Institute for the promotion of higher education (ICFES). 
In the case of qualitative inquiry, the Compartir Report's consultancy team has vigorosly agreed to defend the assumption that their visits to schools serve to verify their quantitative results. Leaving asside their ambigous statement about causality (in the sense that their model is not causal, but both their model and their qualitative inquiry do serve to identify the major determinant of school performance), it is worth pointing out the way in which their qualitative questionnaries were built to retrieve findings only in the spectrum of teaching quality. The latter obeys a more deductive logic ${ }^{15}$ where they now try to go from a theoretical prescription (bulk on the econometric results) to an empirical validation. The problem, once again, is the implicit assumption of researching in a closed-system.

How does this affect the inclusion of teachers' voices in public policy debates? As we have anticipated, methodological preferences for statistical representativeness (as a means to identify, for example, empirical regularities) bare the consequence of disregarding the skills of scholars in education (not always equipped to talk in terms if statistics) and the experience of actual teachers (under the label of anecdotal evidence). Conversely, the role given to induction and deduction in positivist research not only generates ontic and epistemic problems, but coheres with a logic of overweighting pre-structured research (i.e. pre-structured econometric specifications, pre-structured qualitative questionnaires to validate previous findings) in which the assumptions of the researcher (i.e. rational behavior) lead him/her to overshadow a more active role of the researched.

\section{Involving Teachers and Professional Educators}

So far, CR has helped us to identify problems in mainstream educational research. In this last section we are now interested in doing some progress towards alternative research agendas -and with particular focus in the problem at stake: the inclusion of the voices of educators in policy debates. The broad implication of our reading of the Compartir Report is the identification of lack of good science immersed in dominant education policy. Hence, we seek to praise good scientific practices, under whose logic we can argue, "different methods [and

${ }^{15}$ Or a way “...to explain and predict particular empirical phenomena by deducing them from a set of propositions about general regularities or universal laws and precisely specified initial conditions" (Wuisman, 2005, p. 367). 
voices] can be seen to be necessary to reveal different aspects of the constituency of [social] phenomena" (Downward \& Mearman, 2007, p. 91).

A question that follows is how can we establish a research design that conceives stratification but without falling into the assumption of a closed-system? Put in simpler terms, how can we study social phenomena (i.e. school performance) without falling into either crude empiricism or problematic forms of quantitative modeling? We believe that Scott and Usher's (2011) text on methods for researching education provides a (fairly) straightforward answer:

Structures and mechanisms are not immediately available to consciousness, and therefore, the first stage of the process is to construct a possible model of them, drawing on evidence from what is observable (...). The next stage is to test the model. If the testing is successful, this allows the researcher to believe or at least to have good grounds for believing in the existence of these structures and mechanisms. The whole process may be repeated so that the existence of these structures and mechanisms is confirmed. (p. 54)

While this idea might require further elaboration ${ }^{17}$, it does provide important elements to sustain our main argument. On one hand, scientific discovery necessarily begins with what is observed, at which moment tools such as statistics can contribute to clarify the empirical strata of social reality (Dow, 2003; Downward \& Mearman, 2007). Here we would open space for the work of expert statisticians and the application of large-scale quantitative analysis. However, the art of identifying underlying mechanisms does imply an exercise of testing, repetition and iteration. Under such circumstances, CR researchers show preference for more ethnographic research (Ackroyd, 2009) to allow an intensive interaction with social actors that have a primary involvement with the problem at hand.

Here, however, we need social theory that serves the purpose of giving empirical sense to these types of reasoning. In this regard, commentators have exalted Archer's $(1995,2003)$ approach (Porpora

${ }^{16}$ Put in more formal terms, "the concept of cause in critical realism is tied to emergence from the interaction of human agency and institutions or structures. In this regard, the motivational (or otherwise) dimension of agency needs to be elaborated, as well as the mechanisms that facilitate action, or behaviour, coupled with the relational context of that behaviour. Each of these components clearly requires different methods of analysis to reveal their nature and action" (Downward \& Mearman, 2007, p. 91).

17 We encourage interest readers to consult Wuisman's (2005) work on CR methodology. 
D. , 2013, p. 25), as it has devoted an important conceptual effort to elucidate the logic of relational emergence in social systems. One of Archer's (2003) crucial statements- and which gives sense to the stratified nature of the social word - is the idea that "the causal power of social forms is mediated through agency" (p. 2). It is to say, while social agents might be not aware of generative mechanisms acting on them, the existence of causal structures is expressed through the shaping of social behavior and interactions. This last argument positions the experience of directly involved social actors (i.e. teachers in the context of education policy) in the identification of causal knowledge ${ }^{18}$.

One example of Archer's model at work is Wallace \& Priestley's (2011) and Priestley \& Miller's (2012) research in Scotland. When dealing with the complex issue of why exogenous (i.e. national) education policies often fail to change life in schools, the authors "recognize the inevitability of teacher mediation of policy" (Priestley \& Miller, 2012, p. 100) to study how cultural forms and social structures "constrain teacher agency, and how certain teachers are able to bring to bear particular experiences and values in acting within these constraints" (Wallace \& Priestley, 2011, p. 363). The latter led them to establish a research design that included an active participation of teachers from different knowledge fields (i.e. language, math, natural sciences) to answer questions directed towards the understanding of possible changes in pedagogy and curriculum boosted by different initiatives of the Scottish educational authority - the Highland Council-.

What is important to emphasize here is the way CR ontology helped the authors to address non-observable causes boosting or restraining change in schools. This was the case of one teacher, Vanessa, who self-reported that she believed that she "encouraged pupils to think for themselves" (Wallace \& Priestley, 2011, p. 371). However, after recording her class, researchers were able to identify that she actually performed in the classroom as if "pupils were unable to think critically" (p. 371), a fact that reflected her belief that students were "irresponsible, and lazy" (p. 371). In such sense, observed (lack of) change in classroom dynamics was explained by interacting contradictions between different cultural influences that could only be

18 This, however, does not mean that it is enough to ask actors about their experience in order to identify a causal explanation. The latter would imply working only in the level of the empirical (or perception). In Archer's (2013) words, "The prior educational context is not assumed to be exactly as contemporary actors described it (...) because (...) social contexts cannot simply be reduced to what contemporary actors think, or thought about them, for this world would be endorse the autonomy to the present tense" 
accessed through an empirical fact (i.e. an expressed perception) but fully understood by linking it with an indirectly unobserved one (i.e. preference for authority, reflected in Vanessa's way of teaching).

Another good example of CR grounded social theory is Willmot's $(1999,2001)$ five-month ethnographic research in a low-academicperforming school. Here the author makes use of Archer's framework to exalt the role of actors' deep knowledge about their context (active teachers) in helping to unveil underlying causal mechanisms explaining students' low SAT scores. One of his main conclusions, which states the existence of "a fundamental contradiction between the child-centered (humanist) concern for behaviour and self-esteem and the strategic manipulation of managerialism, which denies the very humanistic path that facilitates (potentially) success in [test scores]" (Willmott, 2002, p. 166), was only possible to identify through extensive observations and frequent conversations with school teachers. The latter, because, in line with the core arguments of this paper, such particular dynamics were "erased out of existence by the ontological presuppositions of [the Office for Standards in Education] positivist framework!" (Willmott, 1999$, p. 8$)^{19}$.

19 This last idea matches with Lawson (2012)'s comment on how policy prescriptions informed by assumptions of closure might trivialize particular aspects of human interactions - for instance, cases of segregation, and discrimination, more commonly enclosed in day-to-day actors' interactions- that can impact desirable policy outcomes. Positivist-based research in particular, he argues, is "ill-equipped even to allow such categories to be seriously considered" (p. 17). 


\section{Conclusion}

Throughout this document, we have engaged in a challenging, but arguably urgent, issue: the need to more actively involve teachers in education policy debates. The paper introduces CR as an alternative to dominant research paradigms in education that serves the inclusion of professional educators in education politics. The latter, in response to some methodological pitfalls that characterize mainstream educational research.

We argue that because we live in an open world, we need research methodologies that transcend inductive and deductive inference logics to theorize about the unobserved -or those relational conditions (that have an ontic status) that presuppose the existence of social objects/ practices-. Here we introduced some elements of Archer's (1995, 2003) social theory -and discussed some of its possible practical implications in empirical research- to argue the way in which the intensive knowledge possessed by professional educators (i.e. teachers) about their field becomes a key-factor to build causal knowledge about the role of education in society.

In the end, we argue that traditional top-down approaches in education planning have proven to be quite ineffective -at least in the Colombian context- not only because they might be serving particular vested interests in society (for instance, instrumentalizing education in order to serve the purposes of industry), but due to their they lack of scientific rigor. In such a sense, if we seek to rectify education as a motor for social change, we need to modify the way in which we theorize about education policy. The idea is that many actors might and should contribute to the debate (because reality is stratified), but without disregarding the potentialities and limitations of different researchers in the field. 


\section{References}

Ackroyd, S. (2009). Research designs for realist research. In The SAGE handbook of organizational research methods. London: Sage.

Álvarez, A. (2014). Los límites de la economía de la educación: abrir la mirada. Revista Colombiana de Educación, (67), 19-46.

Archer, M. (1995). Realist social theory: The morphogenetic approach. Cambridge: Cambridge University Press.

Archer, M. (2003). Structure, agency and the internal conversation. Cambridge: Cambridge University Press.

Archer, M. (2013). Social origins of educational systems. London: Routledge.

Barrera, F., Maldonado, D., \& Rodriguez, C. (2012). Calidad de la educación básica y media en Colombia: Diagnóstico y propuestas. Bogotá: Universidad de los Andes, Serie Documentos Cede, 201241.

Bhaskar, R. (1998). The possibility of naturalism. A philosophical critique of the contemporary human sciences (3rd ed.). London: Routledge.

Bhaskar, R., \& Hartwig, M. (2010). The formation of Critical Realism. London: Routledge.

Braun, H. (2008). Review of McKinsey report: How the world's best performing school systems come out on top. Journal of Educational Change, 9, 317-320.

Bunge, M. (2011). Knowledge: Genuine and bogus. Science \& Education, 20(5-6), 411-438.

Coffield, F. (2012). Why the McKinsey reports will not improve school systems. Journal of Education Policy, 27(1), 131-149.

Collier, A. (1994). Critical Realism: An introduction to Roy Bhaskar's philosophy. London: Verso.

Danermark, B., Ekstroem, M., Jacobsen , \& Karlsson, J. (2002). Explaining society: Critical Realism in the social sciences. New York: Psychology Press.

Dow, S. (2003). Critical Realism and economics. In P. Downward (Ed.), Applied economics and the Critical Realist critique (pp. 11226). London: Routledge. 
Downward, P., \& Mearman, A. (2007). Retroduction as mixed-methods triangulation in economic research: Reorienting economics into social science. Cambridge Journal of Economics, 31(1), 77-99.

Elder-Vass, D. (2010). The causal power of social structures. Cambridge: Cambridge University Press.

García-Villegas, M., Espinosa, R., Jimenez, F., \& Parra, J. (2013). Separados y desiguales: Educación y clases sociales en Colombia. Bogotá: Editorial Dejusticia.

Gertler, P., Martinez, S., Premand, P., Rawlings, L., \& Vermeersch. (2011). Impact evaluation in practice. Washington, DC: The World Bank.

Greene, P. (2014, August 20). Missing the Teacher Voice. Education Week.

Herrera, M., \& Acevedo, R. (2004). Las políticas públicas y su impacto en el sistema educativo colombiano: Una mirada desde los planes de desarrollo 1970-2002. Nómadas(20), 76-85.

ICFES. (2012). Estudios sobre calidad de educación en Colombia. Bogotá: Instituto Colombiano para la Evaluación de la Educación.

Jaramillo, S., Maldonado, D., Perry, G., Rodríguez, C., \& Saavedra, J. (2014). Tras la excelencia docente. Cómo mejorar la calidad de la educación para todos los colombianos. Bogotá: Fundación Compartir.

Johansson, U. (2003). Frame Factors, Structures, and Meaning Making: Shifting Foci of Curriculum Research in Sweden. In W. Pinar (Ed.), International handbook of curriculum research (pp. 575-593). Mahwah, NJ: Lawrence Erlbaum Associates.

Judd, J., Frankish, J., \& Moulton, G. (2001). Setting standards in the evaluation of community-based health promotion programmes - a unifying approach. Health Promotion International , 16(4), 367-380.

Kanbur, R., \& Shaffer, P. (2007). Epistemology, normative theory and poverty analysis: Implications for Q-squared in practice. World Development, 35(2), 183-196.

Lawson, T. (1997). Economics and reality. London: Routledge.

Lawson, T. (2012). Mathematical modelling and ideology in the economics academy: Competing explanations of the failings of the modern discipline? Economic Thought, 1(1), 3-22. 
Mahoney, J., \& Vincent, S. (2014). Critical Realism as an empirical project: A beginner's guide. In P. Edwards, J. O’Mahoney, \& S. Vincent (Eds.), Studying organizations using Critical Realism: A practical guide (pp. 1-20). Oxford: Oxford University Press.

Milani, C. (2009). Evidence-based policy research: Critical review of some international programmes on relationships between social science research and policy-making. France: United Nations Educational, Scientific and Cultural Organisation, UNESCO, Policy Papers / 18.

Montoya-Vargas, J. (2014). The field of curriculum studies in Colombia. In W. Pinar, (Ed.), International handbook of curriculum research, Vol 2 (pp. 134-150). London: Routledge.

Parada, J. (2004). Realismo Crítico en investigación en ciencias sociales: Una introducción. Investigación y Desarrollo , 12(2), 396429.

Porpora, D. (2001). Do Realists run regressions? In J. López, \& G. Potter (Eds.), After Postmodernism: An introduction to Critical Realism (pp. 260-268). London: The Athlone Press.

Porpora, D. (2013). Morphogenesis and social change. In M. Archer (Ed.), Social morphogenesis (pp. 25-38). Lausanne: Springer.

Priestley, M., \& Miller, K. (2012). Educational change in Scotland: Policy, context and biography. The Curriculum Journal, 23(1), 99116.

Sayer, A. (2000). Realism and social science. London: SAGE Publications.

Sayer, A. (2012). Power, causality and normativity: A Critical Realist critique of Foucault. Journal of Political Power, 5(2), 179-194.

Scott, D. (2010). Education, epistemology and Critical Realism. London: Routledge.

Scott, D., \& Usher, R. (2011). Researching education: Data, methods and theory in educational enquiry (2 ed.). London: Continuum International Publishing Group.

Summer, A., \& Tribe, M. (2008). International development studies: Theories and methods in research and practice. London: Sage.

Wallace, C., \& Priestley, M. (2011). Teacher beliefs and the mediation of curriculum innovation in Scotland: A socio-cultural perspective on professional development and change. Journal of Curriculum Studies, 43(3), 357-381. 
Willmott, R. (1999). Structure, agency and school effectiveness: Researching a 'failing' school. Educational Studies, 25(1), 5-18.

Willmott, R. (2002). Education policy and Realist social theory. Primary teachers, child-centered philosophy and the new managerialism. London: Routledge.

Wuisman, J. (2005). The logic of scientific discovery in critical realist social scientific research. Journal of Critical Realism, 4(2), 366-394.

Zeeman, L., Pogenppoel, M., Myburg, C., \& Van Der Linde, N. (2002). An introduction to postmodern approach to educational research: Discourse analysis. Education, 123(1), 96-102.

\section{Author}

Juan David Parra* is a PhD Candidate at the International Institute of Social Studies, Erasmus University Rotterdam. He holds a Master's degree in economics. His on-going doctoral research delves into the paradigm of Critical Realism -and relevant social theory- to explore causes of poor school performance in regions of Colombian. 


\section{Appendix}

\section{Research in the Quality of Education Funded and Published by ICFES in 2012}

\begin{tabular}{|c|c|c|c|}
\hline Research title & \begin{tabular}{|c|} 
Area/discipline \\
of the \\
researcher(s)
\end{tabular} & Methods & Data sources \\
\hline $\begin{array}{l}\text { Analysis of the evaluation of } \\
\text { equality of opportunities in } \\
\text { secondary education, an } \\
\text { international perspective. The } \\
\text { Case of Colombia. }\end{array}$ & $\begin{array}{c}\mathrm{PhD} \text { in } \\
\text { Economics }\end{array}$ & $\begin{array}{l}\text { Estimation of an } \\
\text { index of inequality } \\
\text { in education } \\
\text { opportunity }\end{array}$ & $\begin{array}{l}\text { PISA } 2006 \text { and } \\
2009 \text {, Saber } 11\end{array}$ \\
\hline $\begin{array}{l}\text { Practices in educational } \\
\text { institutions in Bogotá City } \\
\text { related with the preparation for } \\
\text { Saber } 11 \text { exams. Contrast } \\
\text { according to performance level } \\
\text { and socio-cultural context }\end{array}$ & \begin{tabular}{|} 
Psychologist, \\
Master in \\
Social Sciences \\
and PhD in \\
Psychology
\end{tabular} & $\begin{array}{l}\text { Survey analysis and } \\
\text { discourse analysis }\end{array}$ & $\begin{array}{l}102 \text { Surveys and } \\
\text { qualitative } \\
\text { interviews in } 4 \\
\text { schools }\end{array}$ \\
\hline $\begin{array}{l}\text { What is the gap in education } \\
\text { quality in Colombia in } \\
\text { secondary and undergraduate } \\
\text { education? }\end{array}$ & $\begin{array}{l}\text { Maters in } \\
\text { Economics }\end{array}$ & $\begin{array}{l}\text { Multilevel } \\
\text { econometric } \\
\text { estimates }\end{array}$ & $\begin{array}{c}\text { Saber } 11 \text { and Saber } \\
\text { Pro }\end{array}$ \\
\hline $\begin{array}{l}\text { An analysis of the effect of } \\
\text { peers over academic } \\
\text { performance in Colombia }\end{array}$ & Economics & $\begin{array}{l}\text { Multilevel } \\
\text { econometric } \\
\text { estimates and } \\
\text { regressions by } \\
\text { quintiles }\end{array}$ & PISA 2006 \\
\hline $\begin{array}{l}\text { Meritocracy in teaching } \\
\text { careers: Evidence from } \\
\text { Colombia }\end{array}$ & Public Policy & $\begin{array}{l}\text { Fixed effects } \\
\text { econometric } \\
\text { estimates }\end{array}$ & $\begin{array}{l}\text { Saber } 11, \text { data from } \\
\text { teacher's } \\
\text { evaluations, dropout } \\
\text { rates }\end{array}$ \\
\hline $\begin{array}{l}\text { Individual Determinants of } \\
\text { performance in State exams } \\
\text { for secondary education en } \\
\text { Colombia }\end{array}$ & Not specified & $\begin{array}{l}\text { Multilevel } \\
\text { econometric } \\
\text { estimates and } \\
\text { regressions by } \\
\text { support vectors }\end{array}$ & Saber 11 \\
\hline $\begin{array}{l}\text { More than infrastructure: the } \\
\text { neighborhood effect of public } \\
\text { libraries in the quality of } \\
\text { education }\end{array}$ & Economics & $\begin{array}{l}\text { Difference in } \\
\text { difference } \\
\text { econometric } \\
\text { estimates }\end{array}$ & $\begin{array}{l}\text { C100 y C600 forms } \\
\text { with school data, } \\
\text { National Census } \\
\text { 2005, Saber } 11\end{array}$ \\
\hline
\end{tabular}

